\title{
Performance of Pleurotus ostreatus mushroom grown on maize stalk residues supplemented with various levels of maize flour and wheat bran
}

\author{
Senzosenkosi Surprise MKHIZE ${ }^{1 \star}$, Jacques CLOETE ${ }^{2}$, Albertus Kotze BASSON${ }^{1}$, Godfrey Elijah ZHARARE ${ }^{3}$
}

\begin{abstract}
Improving the performance of mushroom in terms of high production and fast growth rate is essential in mushroom cultivation. In the present study the performance of Pleurotus ostreatus was evaluated using varying levels of wheat bran (WB) and maize flour (MF). The results indicated that Pleurotus ostreatus was highly influenced by different levels of supplementation, with $8 \% \mathrm{WB}, 18 \% \mathrm{WB}$ and $2 \% \mathrm{MF}$ having higher contamination rate. The low levels of supplementation gave significantly better mycelial growth rate (MGR) and shorter colonisation period as observed that the control had highest MGR whereby $20 \%$ MF had lowest MGR. The pinning time (TP) was shortest at the first flush with minimum of 3 days (12\% MF). The higher levels of supplementation showed maximum biological efficiency (BE) such as $14 \% \mathrm{MF}, 12 \% \mathrm{WB}$ and $14 \% \mathrm{WB}$. The yield was also higher at high levels of supplementation such as $20 \% \mathrm{MF}$ and $8 \% \mathrm{MF}$ being the exception in the lower levels. Based on the results it was observed that for fast production of oyster mushroom there is no need to supplement the maize stalk substrate but for improved productivity supplements can be added up to certain limits such as $14 \%$ MF and $12 \mathrm{WB}$.
\end{abstract}

Keywords: biological efficiency; Pleurotus ostreatus; supplement; maize stalk

Practical Application: The study will add to the pool of scientific knowledge relating to optimum substrate formulations (supplements) involving maize residues for Pleurotus ostreatus mushroom production. The results observed can be useful to small scale farmers who are willing to obtain good yield within minimal time at minimal cost with reduced contamination problems. Based on the results obtained, it is recommended that for fast production there is no need to add supplements on maize stalks but for improved production supplements can be added up to certain limits.

\section{Introduction}

Oyster mushrooms, such as Pleurotus ostreatus, are not usually attacked by both diseases and pests and their cultivation does not require sophisticated control of the growing environment, hence they are cultivated in a cheap and easy way (Kües \& Liu, 2000; Sánchez, 2010). The Pleurotus ostreatus mushroom has gained popularity within the Southern African Development community (SADC) (Earnshaw et al., 2012), because of its pleasant flavour and taste (Khan et al., 2012). In addition, the mushroom has potential for livestock feed and for extraction of enzymes and medicinal compounds (Patil et al., 2010).

According to Garg \& Gupta (2009) plant derived agro-industrial waste cause environmental and health problems. This waste can be managed through mushroom cultivation, since mushrooms have the ability to grow on a variety of raw lignocellulosic substrates and under a wide range of temperatures (Jandaik \& Goyal, 1995; Sánchez, 2010). Oyster mushrooms (Pleurotus spp.) are able to perform such duties, because they contain a number of nonspecific lignocellulosic enzymes (Zhang et al., 2002) which have a major impact in the development and growth of the mushroom (Kuforiji \& Fasidi, 2008). The nature and nutrient constituent of the mushroom substrate also have an effect on the mycelium growth, mushroom quality and crop yield (Baldrian \& Val'a skov’a, 2008; Kües \& Liu, 2000). One of the limiting factors in the cultivation of mushrooms is that the availability of a good substrate is essential in order to promote satisfactory yield of the mushrooms (Ueitele et al., 2014). A good substrate should consist of nitrogen supplement and carbohydrates in order to promote rapid growth of the mushroom (Ogundele et al., 2014). In most cases the substrate does not have the nitrogen required by the mushroom to grow optimally, hence the need for nitrogen supplementation of the substrate in order to gain an improved growth of the mushroom (Choi, 2004).

Although supplementing the substrate material leads to improved growth, there are limitations involved. For instance, high supplementation of substrate may lead to contamination (Yildiz et al., 2002) together with reduced yield of the mushrooms (Fanadzo et al., 2010). A variety of substrate supplements have been recommended for oyster mushrooms. These supplements include, but are not limited to, urea, ammonium sulphate, gram flour, molasses, mustard cake, soy bean meal and cotton seed cake (Ralph \& Kurtzman, 1994). Wheat bran supplements are effective in improving mushroom productivity and also 
the inclusion of maize additive shows an increase in both the nutritional value and productivity of mushrooms (Oei, 2005).

This study focussed on utilizing maize stubble as substrate for oyster mushroom (Pleurotus ostreatus) production in the Northern Kwa-Zulu Natal (South Africa) areas. The information scarcity on supplements required to improve yields of Pleurotus ostreatus mushroom with minimum contamination guided the research in order to determine the performance of Pleurotus ostreatus on maize stalks with varied levels of wheat bran and maize flour supplement. The results of the study will be crucial to poor rural communities which utilizes local maize residue material for Pleurotus ostreatus mushroom production for both food and income generation.

\section{Materials and methods}

\subsection{Supplements and substrates collection}

The maize residues (leaves and stalks) were obtained from farms in and around the northern Kwa-Zulu Natal area (University of Zululand and local community farms) and stored at room temperature. The vitamin free maize flour supplement was obtained from Empangeni millers and the wheat bran was obtained from Coastal Farmers (local market).

\subsection{The test mushroom strain}

The test oyster mushroom (Pleurotus ostreatus) was obtained from Cedara College of Agriculture at Pietermaritzburg in Kwa-Zulu Natal (South Africa). The mushroom strain was pre-cultured on potato dextrose agar (PDA) (MERCK, 1.10130) and incubated at $25^{\circ} \mathrm{C}$. These were maintained as working spawn cultures in a refrigerator at $4{ }^{\circ} \mathrm{C}$ in order to preserve the mushroom in it active state.

\subsection{Preparation of mushroom spawn}

A modified method outlined by Fritsche (1978) was used to prepare the spawn, whereby $1 \mathrm{~kg}$ of sorghum grain was soaked overnight in 1.5 litres of water and the excess water was thereafter drained from the grains. A quantity of $900 \mathrm{~g}$ of the grains was mixed with $12 \mathrm{~g}$ of the gypsum and $3 \mathrm{~g} \mathrm{CaCO}_{3}$. The mixture was packed halfway into $250 \mathrm{ml}$ bottles. The grain in the $250 \mathrm{ml}$ glass bottles were sterilised at $121^{\circ} \mathrm{C}$ in an autoclave (Labtech, LAC5060S) for 15 minutes and allowed to cool to room temperature. The sterilised sorghum grain mixture was inoculated with $10 \mathrm{~mm}^{2}$ of previously grown pure cultures of Pleurotus ostreatus strain using a flamed and cooled scalpel in a laminar flow hood. The inoculated bottles were incubated in the dark at room temperature $\left(25^{\circ} \mathrm{C}\right)$ for two weeks until the mycelium had fully colonised the grain.

\subsection{Bulk substrate preparation}

The substrate was prepared using a modified version of the method proposed by Bano \& Srivastava (1962). The maize stalks were milled using the milling tractor machine and thereafter the dry weight of maize stalks was measured. This assisted in the analysis of the results (especially, biological efficiency). Tap water was added to the substrate to achieve $65 \%$ moisture content using the rule of thumb (1-2 droplets of water must be released when the substrate is squeezed). Thereafter, the maize stalk substrates were separately supplemented with 8 levels of maize flour and wheat bran, viz; $0 \%, 2 \%, 4 \%, 8 \%, 12 \%, 14 \%, 18 \%$ and $20 \%$ respectively. After the supplements were added and thoroughly mixed with the base substrates, $1 \mathrm{~kg}$ of the resultant substrate was packed into polypropylene bags $(22.5 \mathrm{~cm} \times 30 \mathrm{~cm})$ in four replicates and compressed by hand until compactness was achieved. The bagged substrates were pasteurised at $60-65^{\circ} \mathrm{C}$ for six hours (Jang et al., 2003) and allowed to cool to room temperature.

\subsection{Substrate inoculation, spawn running and fruiting}

After cooling, all the bagged substrates were inoculated with previously prepared pure grain spawn of the Pleurotus ostreatus mushroom at the rate of $2 \%$ of wet substrate. The Pleurotus ostreatus was grown in four replicates for every level of supplemented substrate. Inoculation was strictly conducted in a sterile environment (laminar flow hood) using one spoonful of mother culture placed aseptically into the top surfaces of each bag with substrates. The inoculated substrates were tightly closed with cotton wool and rubber bands to hold it in place. The cotton wool was used as plugs that prevented contamination into bags but allowed gaseous exchange. The inoculated bags were incubated in a dark room at $25-27^{\circ} \mathrm{C}$ until they became fully colonised. Thereafter the bags were transferred to a fruiting room which was constructed from plastic film supported by gum poles and covered by a double layer of $60 \%$ shade cloth on the outside. The fruiting room was under the canopy of a Zygium tree, which is an evergreen tree and hence provided shade throughout the year. The fruiting room was fitted with timed micro-jet sprinklers that watered the mushrooms in a fine spray at least three times a day in order to obtain $80-90 \%$ relative humidity. The mushrooms were allowed to fruit under ambient temperatures. The experiment was terminated after 3 fruiting flushes.

\subsection{Performance/productivity measurements}

In order to determine the performance and how does the supplements affect the performance of $P$. ostreatus when grown on maize stalk different parameters were checked. The parameters that were measured for performance of $P$. ostreatus included the number of contaminated bags, mycelial growth rate, number of days to full colonisation, time to fruiting (initiation of pin heads), fresh mushroom yield and biological efficiency. The number of contaminated bags for each and every treatment was recorded or counted manually. The advancement of mycelium down the substrate bag was ringed at 6 day intervals until the substrate was fully colonised. The rate of colonisation of the substrate by the mushroom mycelia was then estimated by measuring the distance from the top down to each of the rings at four equally spaced points around the bag using a marked ruler. The number of days it took for the mycelia to fully colonise the substrate was also noted from the time it first colonised the substrate up to a point where the mycelia full covered substrate. Immediately after mycelia full colonised the substrate, the bags were taken to fruiting room where the bags were opened on the top part and the time taken for pin head formation after the full colonisation 
of substrate and after each and every flush was recorded on each replicate.

The mushroom yield was calculated according to Morais et al. (2000), using the equation: MY = [Weight of fresh mushroom harvested (g) per fresh substrate weight]. The biological efficiency was calculated according to (Stamets, 2000; Royse et al., 2004), as follows $\mathrm{BE}=$ [weight of fresh mushroom harvested $(\mathrm{g}) /$ dry substrate weight $(\mathrm{g})] \times 100$.

\subsection{Experimental design and statistical analysis}

The experiment was done in a completely randomised design with 4 replications $(n=4)$. Data was analysed and graphs were constructed using SPSS version 23 and Microsoft Excel. Tests used were Pearson's Correlation, Binomial Test for Proportions, and Repeated Measures ANOVA followed by post hoc Duncan's homogeneous groups. A 5\% level of significance was used throughout.

\section{Results}

\subsection{The number of contaminated bags}

There were eight (12.5\%) contaminated bags from a total of sixty four. This indicates that the Pleurotus ostreatus mushroom was not highly susceptible to contamination. From the total of eight contaminated bags, high contamination was observed at $18 \% \mathrm{WB}, 8 \% \mathrm{WB}$, and $2 \% \mathrm{MF}$ (with $50 \%$ of replicates), and the lowest contamination was observed at $12 \% \mathrm{MF}$, and $2 \% \mathrm{WB}$ (with $25 \%$ of replicates) respectively (Table 1 ). The maize flour supplement contained a total of three $(9.3 \%)$ contaminated bags whereas wheat bran supplement contained a total of five (15.6\%) contaminated bags. The proportion of contaminated bags are not significantly different between the two supplements $(p=0.4005)$. Over time the contamination was overcome and only $2 \% \mathrm{WB}$ yielded two flushes whereas the other seven yielded three flushes.

\subsection{Mycelial growth rate of Pleurotus ostreatus on maize stalk supplemented with different levels of wheat bran and maize flour}

There is a significant negative correlation between supplement level and mycelial growth rate (MGR) of oyster mushroom for $\operatorname{MF}(\mathrm{r}=-0.71 ; p=0.00001)$ and $\mathrm{WB}(\mathrm{r}=-0.59 ; p=0.00075)$ (Figure 1).

There is no significant difference between the average mycelial growth for MF and WB $(p=0.06655)$. The mycelial growth rate (MGR) did differ significantly between supplement levels for both MF and WB $(p=0.0000)$. The MGR ranged from $0.35 \mathrm{~cm} /$ day for $20 \% \mathrm{MF}$ to $0.60 \mathrm{~cm} /$ day for $0 \% \mathrm{WB}$ (Table 2). Supplement levels $14 \%, 18 \%$ and $20 \%$ of both WB and MF showed significantly lower MGR than the control.

\subsection{The number of days to full colonisation of maize stalk substrate by Pleurotus ostreatus mushroom}

The days to full colonisation displayed a significant positive correlation with the supplement level for both $\mathrm{MF}(\mathrm{r}=0.58463$; $p=0.00055)$ and $\mathrm{WB}(\mathrm{r}=0.53651 ; p=0.00270)$ (Figure 2). The average number of days for WB $(39 \pm 1)$ was significantly less than for MF $(43 \pm 1)$ with $p=0.04275$. The number of days to full colonisation of maize stalk ranged from $30 \pm 5$ ( $8 \% \mathrm{WB})$ to $56 \pm 4(20 \% \mathrm{MF})$ (Table 2). The longest periods to full colonisation were observed with $20 \% \mathrm{MF}(56 \pm 4), 14 \% \mathrm{MF}$ $(53 \pm 4)$, and $20 \% \mathrm{WB}(51 \pm 4)$ respectively.

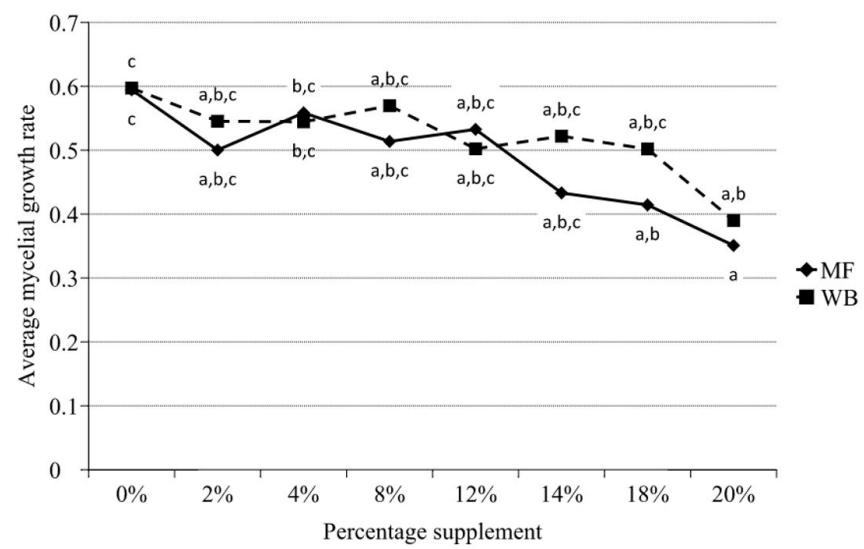

Figure 1. Average mycelial growth rate of Pleurotus ostreatus mushroom per supplement level. (a-e) Averages with different letters are significantly different at $p<0.05$.

Table 1. The effect of wheat bran and maize flour supplements on the number of contaminated bags on the maize stalk base substrate.

\begin{tabular}{ccc}
\hline Treatment & Level & $\begin{array}{c}\text { Number of } \\
\text { contaminated bags }\end{array}$ \\
\hline Maize flour & $2 \%$ & $2(50 \%)$ \\
Maize flour & $12 \%$ & $1(25 \%)$ \\
Wheat bran & $2 \%$ & $1(25 \%)$ \\
Wheat bran & $8 \%$ & $2(50 \%)$ \\
Wheat bran & $18 \%$ & $2(50 \%)$ \\
\hline
\end{tabular}

Table 2. Maize stalk substrate - Effect of WB and MF supplementation on time required for pin head formation (time for pinning) between flushes.

\begin{tabular}{|c|c|c|c|c|}
\hline Supplement & Level & TP flush 1 & TP flush 2 & TP flush 3 \\
\hline \multirow{8}{*}{$\mathrm{MF}$} & $0 \%$ & $4 \pm 0^{\mathrm{a}}$ & $23 \pm 1^{c, d, e, f}$ & $25 \pm 1^{\mathrm{c}, \mathrm{d}, \mathrm{e}, \mathrm{f}}$ \\
\hline & $2 \%$ & $4 \pm 0^{\star \star}$ & $24 \pm 1^{\star}$ & $31 \pm 5^{\star}$ \\
\hline & $4 \%$ & $8 \pm 4^{\mathrm{a}, \mathrm{b}}$ & $20 \pm 3^{\mathrm{c}, \mathrm{d}}$ & $24 \pm 1^{\mathrm{cd}, \mathrm{d}, \mathrm{e}, \mathrm{f}}$ \\
\hline & $8 \%$ & $8 \pm 3^{*}$ & $22 \pm 2^{*}$ & $25 \pm 1^{*}$ \\
\hline & $12 \%$ & $3 \pm 0^{\mathrm{a}}$ & $23 \pm 3^{c, d, e, f}$ & $23 \pm 0^{c, d, e, f}$ \\
\hline & $14 \%$ & $6 \pm 3^{\mathrm{a}, \mathrm{b}}$ & $30 \pm 3^{\mathrm{f}}$ & $27 \pm 7^{\mathrm{c}, \mathrm{d}, \mathrm{e}, \mathrm{f}}$ \\
\hline & $18 \%$ & $5 \pm 1^{*}$ & $26 \pm 2^{*}$ & $28 \pm 5^{\star}$ \\
\hline & $20 \%$ & $6 \pm 1^{\mathrm{a}, \mathrm{b}}$ & $30 \pm 2^{f}$ & $30 \pm 2^{\mathrm{f}}$ \\
\hline \multirow{8}{*}{ WB } & $0 \%$ & $4 \pm 0^{\mathrm{a}}$ & $23 \pm 1^{c, d, e, f}$ & $25 \pm 1^{\mathrm{c}, \mathrm{d}, \mathrm{e}, \mathrm{f}}$ \\
\hline & $2 \%$ & $4 \pm 0^{*}$ & $24 \pm 1^{\star}$ & $30 \pm 2^{*}$ \\
\hline & $4 \%$ & $6 \pm 1^{\mathrm{a}, \mathrm{b}}$ & $21 \pm 1^{\mathrm{c}, \mathrm{d}, \mathrm{e}}$ & $28 \pm 2^{\mathrm{d}, \mathrm{e}, \mathrm{f}}$ \\
\hline & $8 \%$ & $20 \pm 2^{*}$ & $19 \pm 12^{*}$ & $26 \pm 0^{* * *}$ \\
\hline & $12 \%$ & $12 \pm 4^{\mathrm{b}}$ & $23 \pm 3^{\mathrm{c}, \mathrm{d}, \mathrm{e}, \mathrm{f}}$ & $29 \pm 1^{\mathrm{e}, \mathrm{f}}$ \\
\hline & $14 \%$ & $10 \pm 3^{\mathrm{a}, \mathrm{b}}$ & $19 \pm 1^{c}$ & $23 \pm 2^{\mathrm{c}, \mathrm{d}, \mathrm{e}, \mathrm{f}}$ \\
\hline & $18 \%$ & $4 \pm 0^{* *}$ & $20 \pm 2^{*}$ & $36 \pm 1^{*}$ \\
\hline & $20 \%$ & $4 \pm 1^{\mathrm{a}}$ & $29 \pm 1^{\mathrm{f}}$ & $26 \pm 3^{\mathrm{c}, \mathrm{d}, \mathrm{e}, \mathrm{f}}$ \\
\hline
\end{tabular}

${ }^{* * *}$ Based on a single value. ${ }^{* *}$ Based on two or more identical values. ${ }^{*}$ Excluded due to ${ }^{* *}$ and ${ }^{* * *}$. Averages with different superscript in a single column are significantly different at $p \leq 0.05$. 


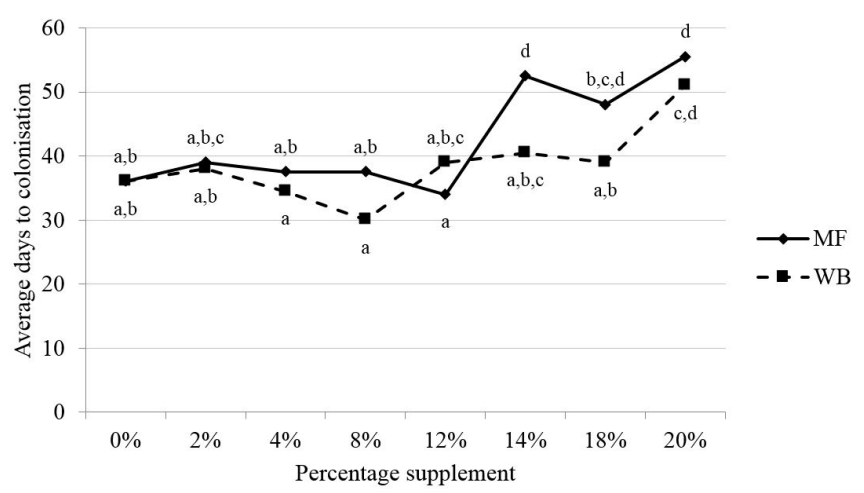

Figure 2. Average days to full colonisation of maize stalk substrate supplemented with different levels of MF and WB. (a-d) Averages with different letters are significantly different at $p<0.05$.

\subsection{Biological efficiency (BE) of Pleurotus ostreatus on maize stalk supplemented with different levels of wheat bran and maize flour}

Biological efficiency is used as a measure of substrate conversion into mushroom (Oseni et al., 2012). There was a positive (non-significant) correlation between supplement level and $\mathrm{BE}$ for $\mathrm{MF}\left(\mathrm{r}_{\mathrm{MF}}=0.4994, p_{\mathrm{MF}}=0.1038\right)$ and a negative (non-significant) correlation between supplement level and $\mathrm{BE}$ for $\mathrm{WB}\left(\mathrm{r}_{\mathrm{WB}}=-0.0145, p_{\mathrm{WB}}=0.5136\right)$ (Figure 3$)$. There was significant interaction between supplements and the level of supplementation $(p=0.0005)$, since the supplements of both WB and MF caused different reaction in BE of Pleurotus ostreatus over different levels of supplementation.

The $\mathrm{BE}$ values ranged from $95 \pm 3$ ( $8 \% \mathrm{WB})$ to $158 \pm 11$ (14\% MF) (Table 2). This range indicated that maize stalk is efficiently profitable for cultivation of Pleurotus ostreatus since it produced BE which was above $50 \%$ as stated by Patra \& Pani (1995). The highest $\mathrm{BE}$ was observed on $14 \% \mathrm{MF}(158 \pm 11)$ and $12 \%$ WB $(156 \pm 6)$ followed by $14 \%$ WB $(148 \pm 3)$. The lowest BE was observed on $8 \%$ WB $(95 \pm 30)$ and $2 \%$ MF $(109 \pm 17)$ (Table 2). When comparing every supplement level from $2 \%$ to $20 \%$ with the control $(0 \%)$, the $12 \% \mathrm{WB}(156 \pm 6), 14 \% \mathrm{WB}$ $(148 \pm 3)$ and $14 \% \operatorname{MF}(158 \pm 11)$ were significantly higher than the non-supplemented maize stalk (control) which had a biological efficiency of $119 \pm 4$.

\subsection{Yield of Pleurotus ostreatus on maize stalk supplemented with different levels of wheat bran and maize flour}

There was significant interaction between supplement and supplement levels $(p=0.0020)$ for Pleurotus ostreatus. This is due to the behaviour of $8 \% \mathrm{WB}$.

The minimum yield was recorded at $8 \% \mathrm{WB}(0.08 \pm 0.03)$ and this was significantly less than the average yields at all other MF and WB levels. The maximum yields were recorded at $20 \% \mathrm{MF}(0.14 \pm 0.01)$ and $8 \% \mathrm{MF}(0.14 \pm 0.01)$ (Table 2), however these were only significantly different from $2 \% \mathrm{MF}$ and $8 \%$ WB. The $8 \%$ WB showed lowest yield due to the presence of contaminants within this level since out of four replicates two of them were heavily contaminated.

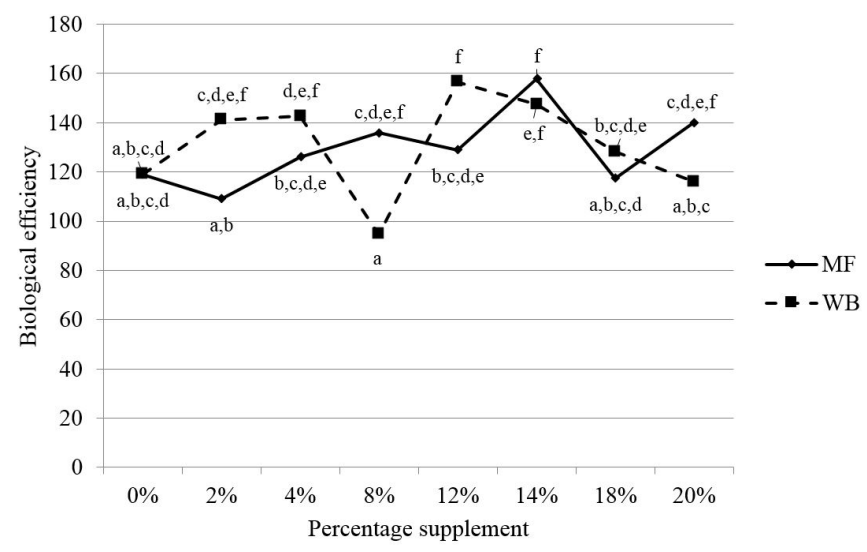

Figure 3. Average biological efficiency of Pleurotus ostreatus mushroom on maize stalk substrate supplemented with different levels of maize flour and wheat bran.

\subsection{Effect of different levels of wheat bran and maize flour on time required for pin head formation (time for pinning) between flushes}

The time for pinning (TP) ranged from 3 days to 36 days based on all flushes. There was a positive correlation between the supplement level and TP (averaged over all 3 flushes) for both MF and WB $\left(\mathrm{r}_{\mathrm{MF}}=0.6092, \mathrm{r}_{\mathrm{wB}}=0.4305\right)$, however the correlations were not significant $\left(p_{\mathrm{MF}}=0.0544, p_{\mathrm{WB}}=0.1435\right)$. The lowest TP for flush 1 was observed to be $12 \% \mathrm{MF}$ ( $3 \pm 0$ days) which was not significantly different from $0 \% \mathrm{MF}, 2 \% \mathrm{MF}, 0 \%$ WB, $2 \% \mathrm{WB}, 18 \% \mathrm{WB}$, and 20\% WB (Table 3). The highest TP for flush 1 was recorded for $8 \%$ WB ( $20 \pm 2$ days) of which $50 \%$ of the replicates initially displayed contamination. The second highest TP for flush 1 is for $12 \% \mathrm{WB}$ (12 \pm 4 days).

The latter was significantly different to the aforementioned minimum values. All the first flush values (except for the anomaly at $8 \% \mathrm{WB}$ which was excluded from the comparison) were significantly different to the second flush and third flush recorded values. The lowest TP for flush 2 is at $14 \% \mathrm{WB}(19 \pm 1)$ and the highest is at $14 \% \mathrm{MF}(30 \pm 3)$ and $20 \% \mathrm{MF}(30 \pm 2)$. The highest and lowest values were significantly different from each other. The only flush $3 \mathrm{TP}$ values that were not comparable with flush 2 values were at $18 \% \mathrm{WB}(36 \pm 1)$. The remaining flush $3 \mathrm{TP}$ values were not significantly different from the flush $2 \mathrm{TP}$ values.

\section{Discussion}

Supplementation of the substrate is of importance in order to increase production of Pleurotus ostreatus mushroom (Estrada et al., 2009) and obtain better yield and development (Carvalho et al., 2010). The lignocellulosic materials have low protein content and therefore supplements are useful in the provision of minerals as phosphorus, potassium and nitrogen for production improvement (Mangat et al., 2008; Moore-Landecker, 1982). In this study maize stalk was supplemented with different levels of wheat bran and maize flour in order to obtain higher growth and yield of mushroom. Although supplements enhanced 
Table 3. Effect of different levels of supplementation of maize flour and wheat bran on growth of Pleurotus ostreatus mushroom.

\begin{tabular}{|c|c|c|c|c|c|}
\hline Supplement & Level & MGR (cm/day) & Days & $\mathrm{BE}$ & MSY \\
\hline \multirow{8}{*}{ MF } & $0 \%$ & $0.59 \pm 0.05^{\mathrm{e}}$ & $36 \pm 4^{\mathrm{a}, \mathrm{b}}$ & $119 \pm 4^{\mathrm{a}, \mathrm{b}, \mathrm{c}, \mathrm{d}}$ & $0.12 \pm 0.00^{\mathrm{b}, \mathrm{c}}$ \\
\hline & $2 \%$ & $0.50 \pm 0.01^{\mathrm{b}, c, \mathrm{~d}, \mathrm{e}}$ & $39 \pm 5^{\mathrm{a}, \mathrm{b}, \mathrm{c}}$ & $109 \pm 17^{\mathrm{a}, \mathrm{b}}$ & $0.11 \pm 0.02^{\mathrm{b}}$ \\
\hline & $4 \%$ & $0.56 \pm 0.04^{\mathrm{e}}$ & $38 \pm 4^{\mathrm{a}, \mathrm{b}}$ & $126 \pm 2^{\mathrm{b}, \mathrm{c}, \mathrm{d}, \mathrm{e}}$ & $0.13 \pm 0.00^{\mathrm{b}, \mathrm{c}}$ \\
\hline & $8 \%$ & $0.51 \pm 0.02^{c, d, e}$ & $38 \pm 4^{\mathrm{a}, \mathrm{b}}$ & $136 \pm 6^{\text {c,d,e,f }}$ & $0.14 \pm 0.01^{\mathrm{c}}$ \\
\hline & $12 \%$ & $0.53 \pm 0.02^{c, d, e}$ & $34 \pm 4^{\mathrm{a}}$ & $129 \pm 7^{\mathrm{b}, \mathrm{c}, \mathrm{d}, \mathrm{e}}$ & $0.13 \pm 0.01^{\mathrm{b}, \mathrm{c}}$ \\
\hline & $14 \%$ & $0.43 \pm 0.03^{\mathrm{a}, \mathrm{b}, \mathrm{c}, \mathrm{d}}$ & $53 \pm 4^{\mathrm{d}}$ & $158 \pm 11^{\mathrm{f}}$ & $0.13 \pm 0.01^{\mathrm{b}, \mathrm{c}}$ \\
\hline & $18 \%$ & $0.41 \pm 0.02^{\mathrm{a}, \mathrm{b}, \mathrm{c}}$ & $48 \pm 4^{\mathrm{b}, c, \mathrm{~d}}$ & $117 \pm 6^{\mathrm{a}, \mathrm{b}, \mathrm{c}, \mathrm{d}}$ & $0.12 \pm 0.01^{\mathrm{b}, \mathrm{c}}$ \\
\hline & $20 \%$ & $0.35 \pm 0.02^{\mathrm{a}}$ & $56 \pm 4^{\mathrm{d}}$ & $140 \pm 9^{c, d, e, f}$ & $0.14 \pm 0.01^{\mathrm{c}}$ \\
\hline \multirow{8}{*}{ WB } & $0 \%$ & $0.60 \pm 0.05^{\mathrm{e}}$ & $36 \pm 4^{\mathrm{a}, \mathrm{b}}$ & $119 \pm 4^{\mathrm{a}, \mathrm{b}, \mathrm{c}, \mathrm{d}}$ & $0.12 \pm 0.00^{\mathrm{b}, \mathrm{c}}$ \\
\hline & $2 \%$ & $0.55 \pm 0.05^{\mathrm{d}, \mathrm{e}}$ & $38 \pm 4^{\mathrm{a}, \mathrm{b}}$ & $141 \pm 6^{\mathrm{cdd}, \mathrm{e}, \mathrm{f}}$ & $0.12 \pm 0.01^{\mathrm{b}, \mathrm{c}}$ \\
\hline & $4 \%$ & $0.54 \pm 0.02^{\mathrm{d}, e}$ & $35 \pm 4^{\mathrm{a}}$ & $143 \pm 4^{\mathrm{d}, e, \mathrm{f}}$ & $0.12 \pm 0.00^{\mathrm{b}, \mathrm{c}}$ \\
\hline & $8 \%$ & $0.57 \pm 0.07^{\mathrm{e}}$ & $30 \pm 5^{\mathrm{a}}$ & $95 \pm 30^{\mathrm{a}}$ & $0.08 \pm 0.03^{\mathrm{a}}$ \\
\hline & $12 \%$ & $0.50 \pm 0.01^{\mathrm{b}, c, \mathrm{~d}, \mathrm{e}}$ & $39 \pm 4^{\mathrm{a}, \mathrm{b}, \mathrm{c}}$ & $156 \pm 6^{\mathrm{f}}$ & $0.13 \pm 0.01^{\mathrm{b}, \mathrm{c}}$ \\
\hline & $14 \%$ & $0.52 \pm 0.05^{c, d, e}$ & $41 \pm 4^{\mathrm{a}, \mathrm{b}, \mathrm{c}}$ & $148 \pm 3^{\mathrm{e}, \mathrm{f}}$ & $0.12 \pm 0.00^{\mathrm{b}, \mathrm{c}}$ \\
\hline & $18 \%$ & $0.51 \pm 0.06^{\mathrm{b}, c, \mathrm{~d}, \mathrm{e}}$ & $39 \pm 5^{\mathrm{a}, \mathrm{b}}$ & $128 \pm 11^{\mathrm{b}, c, \mathrm{~d}, \mathrm{e}}$ & $0.13 \pm 0.01^{\mathrm{b}, \mathrm{c}}$ \\
\hline & $20 \%$ & $0.39 \pm 0.02^{\mathrm{a}, \mathrm{b}}$ & $51 \pm 4^{\mathrm{c,d}}$ & $116 \pm 5^{\mathrm{a}, \mathrm{b}, \mathrm{c}}$ & $0.12 \pm 0.01^{\mathrm{b}, \mathrm{c}}$ \\
\hline
\end{tabular}

Results are mean \pm s.e. MF - maize flour; WB - wheat bran; MGR - mycelia growth rate ${ }^{(\mathrm{a}-\mathrm{e})}$; Days - Days until full colonisation ${ }^{(\mathrm{a}-\mathrm{d})}$; BE - Biological efficiency ${ }^{(\mathrm{a}-\mathrm{f})}$; MSY - Average mushroom yield ${ }^{(\mathrm{a}-\mathrm{c})}$ per gram. Means with different superscript in a single column are significantly different at $(P \leq 0.05)$.

mushroom production, they are however required in moderate quantities in order to avoid yield reduction (Fanadzo et al., 2010) as well as decreasing contamination risk (Miller \& Jong, 1987; Przybylowicz \& Donoghue, 1990; Yildiz et al., 2002). In this study the number of contaminated bags ranged from 1 to 2 (25-50\%) for different level of supplementation. This indicated that Pleurotus ostreatus mushroom was not highly affected by contamination although $18 \% \mathrm{WB}, 8 \% \mathrm{WB}$ and $2 \% \mathrm{MF}$ had slightly higher contamination rates. For $18 \% \mathrm{WB}$ this was most likely due to the fact that high supplementation causes possibility of contamination (Yildiz et al., 2002), since it becomes too rich in nutrients and therefore gravitate the risk of contamination (Oei, 2003). As for $8 \% \mathrm{WB}$ and $2 \% \mathrm{MF}$, the slightly high contamination may most likely be due to partial break down of cellulose and hemicellulose of maize stalk substrate which causes rapid growth of competitor organisms (Balasubramanya \& Kathe, 1996). When comparing both supplements, the wheat bran treatment resulted in slightly more contamination of 5 bags (15.6\%) than maize flour treatment which had 3 bags (9.3\%). This could be a result of the presence of high nitrogen in wheat bran and also high moisture content (Andrade et al., 2007). Overall this study indicated a low rate of contamination. This means that Pleurotus ostreatus was able to colonise maize stalk efficiently and overcome contamination. One of the important factors in mushroom cultivation is the mycelia with exceptional growth (Pokhrel \& Ohga, 2009). In this study the $0 \%$ supplemented maize stalk showed the highest mycelial growth rate $(0.60 \mathrm{~cm} /$ day $)$ followed by $8 \% \mathrm{WB}(0.57 \mathrm{~cm} /$ day $)$ and $4 \% \mathrm{MF}(0.56 \mathrm{~cm} /$ day $)$. These results closely corresponds to the findings by Bhattacharjya et al. (2014) who reported closely related mycelial growth rate on some of the treatment although their study dealt with sawdust as substrate. Such high mycelial growth rate indicated that these level of supplementation consisted of higher carbon to nitrogen ratio $(\mathrm{C} / \mathrm{N})$ which favoured high mycelial growth rate (Yang, 2000). Sarker (2004), established that mycelium running rate of oyster mushroom is influenced by different wheat bran levels of supplementation. In this study, by looking at the growth patterns from Figure 1, there was gradual decline in the mycelial growth rate (MGR) as the supplement level was increased from $0 \%$ to $20 \%$, since the lowest MGR was at 20\% MF and 20\% WB with respective rates $0.35 \mathrm{~cm} /$ day and $0.39 \mathrm{~cm} /$ day. This was probably due to high nitrogen content which is known to inhibit mushroom growth if it is in excessive amount within the substrate (Yang et al., 2013). Therefore the results of the current study support the findings obtained by Naraian et al. (2009) who observed that the increase in the amount of supplements added into the substrate results in the decrease of mycelium growth. The number of days to full colonisation of maize stalk supplemented with both wheat bran and maize powder ranged from 30 to 56 days. The shortest periods observed on $8 \% \mathrm{WB}$ (30 days), $12 \% \mathrm{MF}$ (34 days) and 4\% WB (35 days). This closely corresponds to 34 days reported for Pleurotus ostreatus on sawdust as indicated by Sopit (2006). The longest period to full colonisation was observed at $20 \% \mathrm{MF}$ (56 days). This was not significantly different to $14 \%$ MF (53 days) and 20\% WB (51 days). These closely correspond to 58 days reported by Dlamini et al. (2012) on maize stover. These results contradicts the findings by some researchers who stipulated that Pleurotus ostreatus took 17-20 days to accomplish full colonisation (Ponmurugan et al., 2007; Shah et al., 2004; Vetayasuporn et al., 2006). Mushroom pinning require conditions which are different from those required for mycelial growth (Patrick et al., 2014). The shortest time for pinning (TP) for flush 1 was recorded for 12\% MF (3 days) which was not significantly different to $0 \%$ supplements (control), $2 \% \mathrm{MF}, 2 \% \mathrm{WB}, 18 \% \mathrm{WB}$, and $20 \% \mathrm{WB}$ with TP of 4 days each. The longest TP for flush 1 was recorded for $8 \%$ WB (20 days) and $12 \% \mathrm{WB}$ (12 days). All flush 1 pinning times were significantly shorter than the pinning times for flushes 2 and 3 (Table 3 ). This may be attributed to the decrease in carbon and nitrogen, since the formation of primordia or pin heads is directly related to availability of carbon and nitrogen $(\mathrm{C}: \mathrm{N})$ from lignocellulose substrate (Naraian et al., 2008). The lowest TP for flush 2 is for $14 \% \mathrm{WB}(19 \pm 1)$ and the highest is for $14 \% \mathrm{MF}(30 \pm 3)$ and 
$20 \% \mathrm{MF}(30 \pm 2)$. Flush $3 \mathrm{TP}$ values are not significantly different from the flush 2 TP values except 18\% WB for flush $3(36 \pm 1)$. The current findings corresponds to the results observed by (Obodai \& Vowotor, 2002) who reported that fruiting bodies of Pleurotus eous strain Kapak became apparent within 4 days. These also corresponds to findings by Rühl et al. (2008) who reported 4 days for pinhead formation of Pleurotus ostreatus. This corresponds to our lowest TP for the first flush. Obodai and Vowotor (2002) reported that the Pleurotus quebeca strain $\mathrm{PQB}$ took 35 days. This corresponds closely to $18 \% \mathrm{WB}$ (36 days) for flush 3. Shah et al. (2004) reported almost similar results as they reported that pin head formation ranged from 6-7 days. The largest biological efficiency (BE) was observed on $14 \% \mathrm{MF}$ $(158 \pm 11)$ and $12 \% \mathrm{WB}(156 \pm 6)$ followed by $14 \% \mathrm{WB}(148 \pm 3)$ which was significantly higher than the control with $119 \pm 4$. The lowest biological efficiency (BE) was observed on $8 \% \mathrm{WB}$ $(95 \pm 30)$ and $2 \% \operatorname{MF}(109 \pm 17)$. The reason for lower BE on $8 \%$ WB was the presence of contaminants which competed for space and nutrients. The $\mathrm{BE}$ tend to increase with increase in the level of supplementation, however supplementation above $14 \% \mathrm{MF}$ and $12 \% \mathrm{WB}$ may cause decrease in BE (Figure 3). This may be caused by overheating of substrate which effects the mushroom negatively (Oseni et al., 2012). The obtained BE closely corroborates with the findings of Jafarpour et al. (2011) who obtained BE of $96.13 \%$ on lawn cut complemented with rice bran, $118.20 \%$ on Barley straw with rice bran, and $156.40 \%$ on chop maize complemented with soybean powder and rice bran. The system of adding supplements to the substrates proved to be useful as research have indicated that addition of certain supplements into the substrates improved yield (Kadiri \& Fasidi, 1993; Ukoima et al., 2009). The current study indicated that there is significant interaction between supplement and supplement level $(p=0.0020)$ with yield ranging from lowest of $0.08 \mathrm{~g} / \mathrm{g}$ $(80 \mathrm{~g} / \mathrm{kg})$ to the highest of $0.14 \mathrm{~g} / \mathrm{g}(140 \mathrm{~g} / \mathrm{kg})$. The $8 \%$ wheat bran recorded the lowest yield, but this is most likely due to the contamination in this level of supplementation which might affected the cellulosic content of the substrates. The results obtained indicate that the yield at $8 \%$ MF and 20\% MF levels of supplementation is only significantly higher than the yield at $8 \% \mathrm{WB}$ and $2 \% \mathrm{MF}$. The low yield may be attributed to factors such as contamination and carbon and nitrogen balance within the substrate. Zadrazil (1980) states that substrate low in nitrogen content favours the growth of Pleurotus species and this might have caused the highest yield which was obtained on $8 \% \mathrm{MF}$ and $20 \%$ MF. The yield for this study corresponds favourably with the findings of Pokhrel et al. (2013) who obtained the yield of $153.53 \mathrm{~g}$ on banana leaves with rice bran, $131.28 \mathrm{~g}$ banana leaves with chicken manure, and a lowest yield of $94.90 \mathrm{~g}$.

\section{Conclusion}

The results of the study stipulate that the performance of Pleurotus ostreatus mushroom was highly affected by addition of supplements (wheat bran and maize flour) into the substrate. It was observed that the addition and increase of supplements results in a decrease of the mycelial growth for both wheat bran and maize flour. In addition, the days to full colonisation of the maize stalk tend to increase significantly with an increased level of supplement for both wheat bran and maize flour. The time for pin head (primordia) formation behave in the same way as the level of supplementation is increased. Therefore the mushroom production period is said to be delayed by increasing the level supplementation within the maize stalk substrate. In terms of productivity (biological efficiency and yield), it is clear that an increase in level of supplementation leads to an improved performance of Pleurotus ostreatus mushroom.

\section{References}

Andrade, M. C. N., Kopytowski, J. Fo., Minhoni, M. T. A., Coutinho, L. N., \& Figueiredo, M. B. (2007). Productivity, biological efficiency, and number of Agaricus blazei mushrooms grown in compost in the presence of Trichoderma sp. and Chaetomium olivacearum contaminants. Brazilian Journal of Microbiology, 38(2), 243-247. http://dx.doi.org/10.1590/S1517-83822007000200010.

Balasubramanya, R. H., \& Kathe, A. A. (1996). An inexpensive pretreatment of cellulosic materials for growing edible oyster mushrooms. Bioresource Technology, 57(3), 303-305. http://dx.doi.org/10.1016/ S0960-8524(96)00086-7.

Baldrian, P., \& Val'a skov'a, V. (2008). Degradation of cellulose by basidiomycetous fungi. FEMS Microbiology Reviews, 32(3), 501-521. http://dx.doi.org/10.1111/j.1574-6976.2008.00106.x. PMid:18371173.

Bano, Z., \& Srivastava, H. C. (1962). Studies on cultivation of Pleurotus species on paddy straw. Food Science, 12, 363-365.

Bhattacharjya, D. K., Paul, R. K., Miah, M. N., \& Ahmed, K. U. (2014). Effect of different saw dust substrates on the growth and yield of Oyster Mushroom (Pleurotusostreatus). IOSR Journal of Agriculture and Veterinary Science, 7, 38-46.

Carvalho, C. S. M., Sales-Campos, C., \& Andrade, M. C. N. (2010). Mushrooms of the Pleurotus genus: a review of cultivation techniques. Interciencia, 35(3), 177-182.

Choi, K. (2004). Self cultivation of Oyster Mushroom. Retrieved from http.//www. Mushroom world. com

Dlamini, B. E., Earnshaw, D. M., \& Masarirambi, M. T. (2012). Growth and yield response of Oyster Mushroom (Pleurotus ostreatus) grown on different locally available substrates. Current Research Journal of Biological Sciences, 4(5), 623-629.

Earnshaw, D. M., Dlamini, B., \& Masarirambi, M. T. (2012). Growth and yield of Oyster mushroom (Pleurotus ostreatus) grown on different substrates ammended with varying levels of wheat bran. International Journal of Life Sciences, 1(4), 111-117.

Estrada, A. E. R., Jimenez-Gasco, M. M., \& Royse, D. J. (2009). Improvement of yield of Pleurotus eryngii var. eryngii by substrate supplementation and use of a casing overlay. Bioresource Technology, 100(21), 5270-5276. http://dx.doi.org/10.1016/j.biortech.2009.02.073. PMid:19560343.

Fanadzo, M., Zireva, D. T., Dube, E., \& Mashingaidze, A. B. (2010). Evaluation of various substrates and supplements for biological efficiency of Pleurotus ostreatus sajor-caju and Pleurotus ostreatus. African Journal of Biotechnology, 9, 2756-2761.

Fritsche, G. (1978). Breeding work. In S. T. Chang \& W. A. Hayes (Eds.), The biology and cultivation of edible mushrooms (pp. 239-248). New York: Academic Press.

Garg, V., \& Gupta, R. (2009). Vermicomposting of agro-industrial processing waste. In P. S. N. Nigam \& A. Pandey (Eds.), Biotechnology for agro-industrial residues utilization (pp. 431-456). Netherlands: Springer. http://dx.doi.org/10.1007/978-1-4020-9942-7_24.

Jafarpour, M., Jalalizand, A., \& Eghbalsaied, S. (2011). High fiber media as the most efficient substrates for Pleurotus florida culture. Archives 
of Biological Sciences, 63(3), 889-895. http://dx.doi.org/10.2298/ ABS1103889J.

Jandaik, C. L., \& Goyal, S. P. (1995). Farm and farming of oyster mushroom (Pleurotus sp.). In R. P. Singh \& H. S. Chaube (Eds.), Mushroom production technology (pp. 72-78). Tehri Garhwal: Govind Ballabh Pant University of Agriculture and Technology.

Jang, K. Y., Jhune, C. S., Park, J. S., Cho, S. M., Weon, H. Y., Cheong, J. C., \& Sung, J. M. (2003). Characterization of fruitbody morphology on various environmental conditions in Pleurotus ostreatus. Mycobiology, 31(3), 145-150. http://dx.doi.org/10.4489/MYCO.2003.31.3.145.

Kadiri, M., \& Fasidi, O. (1993). Use of agricultural wastes for the cultivation of Lentinus submidus in Nigeria. Revista de Biologia Tropical, 41, 41-415.

Khan, N. A., Ajmal, M., Haq, M. I. U., Javed, N., Ali, M. A., Binyamin, R., \& Khan, S. A. (2012). Impact of sawdust using various woods for effective cultivation of oyster mushroom. Pakistan Journal of Botany, 44(1), 399-402.

Kües, U., \& Liu, Y. (2000). Fruiting body production in basidiomycetes. Applied Microbiology and Biotechnology, 54(2), 141-152. http:// dx.doi.org/10.1007/s002530000396. PMid:10968625.

Kuforiji, O. O., \& Fasidi, I. O. (2008). Enzyme activities of Pleurotus tuber-regium (Fries) singer, cultivated on selected agricultural wastes. Bioresource Technology, 99(10), 4275-4278. http://dx.doi. org/10.1016/j.biortech.2007.08.053. PMid:17931860.

Mangat, M., Khanna, P. K., Kapoor, S., \& Sohal, B. S. (2008). Biomass and extracellular lignocellulolytic enzyme production by Calocybe indica strains. Global Journal of Biotechnology and Biochemistry, 3, 98-104.

Miller, M. W., \& Jong, S. C. (1987). Commercial cultivation of shiitake in sawdust filled plastic bags. Developments in Crop Science, 10, 421-426. http://dx.doi.org/10.1016/B978-0-444-42747-2.50049-X.

Moore-Landecker, E. (1982). Fundamentals of the fungi (2nd ed.). Upper Saddle River: Prentice-Hall.

Morais, M. H., Ramos, A. C., Matos, N., \& Oliveira, E. J. S. (2000). Note: Production of shiitake mushroom (Lentinus edodes) on ligninocellulosic residues. Food Science \& Technology International, 6(2), 123-128. http://dx.doi.org/10.1177/108201320000600206.

Naraian, R., Sahu, R. K., Kumar, S., Garg, S. K., Singh, C. S., \& Kanaujia, R. S. (2008). Influence of different nitrogen rich supplements during cultivation of Pleurotus florida on maize cobs substrate. The Environmentalist, 29(1), 1-7. http://dx.doi.org/10.1007/s10669008-9174-4.

Naraian, R., Sahu, R., Kumar, S., Garg, S., Singh, C., \& Kanaujia, R. (2009). Influence of different nitrogen rich supplements during cultivation of Pleurotus florida on corn cob substrate. The Environmentalist, 29(1), 1-7. http://dx.doi.org/10.1007/s10669-008-9174-4.

Obodai, M., \& Vowotor, K. (2002). Performance of different strains of Pleurotus species under Ghanaian conditions. Journal of Food Technology in Africa, 7(3), 98-100. http://dx.doi.org/10.4314/jfta. v7i3.19240.

Oei, P. (2003). Mushroom Cultivation- appropriate technology for Mushroom growers (3rd ed.). Leiden: Backhuys Publishers.

Oei, P. (2005). Small scale mushroom cultivation. Agrodok, 40, 65-66.

Ogundele, G. F., Abdulazeez, R. O., \& Bamidele, O. P. (2014). Effect of pure and mixed substrate on Oyster Mushroom (Pleurotus ostreatus) cultivation. Journal of Experimental Biology and Agricultural Science, 2(2S), 215-219. Retrieved from http:www.jebas.org

Oseni, T. O., Dube, S. S., Wahome, P. K., Masarirambi, M. T., \& Earnshaw, D. (2012). Effect of wheat bran supplement on growth and yield of oyster mushroom (Pleurotus Ostreatus) on fermented pine sawdust substrate. Experimental Agriculture \& Horticulture, 30, 40.
Patil, S., Ahmed, S., Telang, S., \& Baig, M. (2010). The nutritional value of Pleurotus ostreatus (JACQ.:FR.) Kumm cultivated on different lignocellulosic agrowastes. Innovative Romanian Food Biotechnology, 7, 66-75.

Patra, A., \& Pani, B. (1995). Evaluation of banana leaf as a new alternative substrate to paddy straw for oyster mushroom cultivation. Journal of Phytological Research, 8, 145-148.

Patrick, F., Mtui, G. Y. S., Mshandete, A. M., \& Kivaisi, A. K. (2014). Ligninolytic enzymes activities of Pleurotus Sapidus P969 during vegetative growth and fruit development on sugarcane residuesbased substrates. International Journal of Biotechnology, 4(3), 58-71.

Pokhrel, K. N., Budathoki, U., \& Yadav, R. K. P. (2013). Cultivation of Pleurotus sajor-caju using different agricultural residues. International Journal of Agricultural Policy and Research, 1(2), 19-23.

Pokhrel, Y. R., \& Ohga, S. (2009). Effects of physical factors and synthetic media on mycelial growth of Lyophyllum decastes. Journal of Ecobiotechnology, 1, 46-50.

Ponmurugan, P., Sekhar, Y. N., \& Sreesakthi, T. R. (2007). Effect of various substrates on the growth and quality of mushrooms. Pakistan Journal of Biological Sciences, 10(1), 171-173. http://dx.doi. org/10.3923/pjbs.2007.171.173. PMid:19070009.

Przybylowicz, P., \& Donoghue, J. (1990). Shiitake growers handbook. Kendall: Hunt Publishing.

Ralph, H., \& Kurtzman, J. (1994). Nutritional needs of mushroomand substrate supplements. In M. C. Nair (Ed.), Advances in mushroom biotechnology (pp. 106-110). Jodhpur: Scientific Publishers.

Royse, D. J., Rhodes, T. W., Ohga, S., \& Sanchez, J. E. (2004). Yield, mushroom size and time to production of Pleurotus cornucopiae (oyster mushroom) grown on switch grass substrate spawned and supplemented at various rates. Bioresource Technology, 91(1), 85-91. http://dx.doi.org/10.1016/S0960-8524(03)00151-2. PMid:14585625.

Rühl, M., Fischer, C., \& Kües, U. (2008). Ligninolytic enzyme activities alternate with mushroom production during industrial cultivation of Pleurotus ostreatus on wheat straw-based substrate. Current Trends in Biotechnology and Pharmacy, 2(4), 478-492.

Sánchez, C. (2010). Cultivation of Pleurotus ostreatus and other edible mushrooms. Applied Microbiology and Biotechnology, 85(5), 13211337. http://dx.doi.org/10.1007/s00253-009-2343-7. PMid:19956947.

Sarker, N. C. (2004). Oyster mushroom (Pleurotus ostreatus) production technology suitable for bangladesh and its nutritional and postharvest behavior (Ph.D. Thesis). Bangabandhu Sheikh MujiburRahman Agricultural University, Gazipur.

Shah, Z. A., Ashraf, M., \& Ishtiaq, C. H. (2004). Comparative study on cultivation and yield performance of Oyster mushroom (Pleurotus ostreatus) on different substrates wheat straw,leaves, saw dust. Pakistan Journal of Nutrition, 3, 158-160. http://dx.doi.org/10.3923/ pjn.2004.158.160.

Sopit, V. (2006). Oyster mushroom cultivation on different cellulosic substrates. Research Journal of Agriculture \& Biological Sciences, 2(6), 548-551.

Stamets, P. (2000). Growing gourmet and medicinal mushrooms (3rd ed., pp. 1-574). Berkley: Ten Speed.

Ueitele, I., Kadhila-Muandingi, N., \& Matundu, N. (2014). Evaluating the production of Ganoderma mushroom on corn cobs. African Journal of Biotechnology, 13(22), 2215-2219. http://dx.doi.org/10.5897/ AJB2014.13650.

Ukoima, H. N., Ogbonnaya, L., Anikpo, G. E., \& Ikpe, F. (2009). Cultivation of Mushroom on various farm wastes in Obubra local. Pakistan Journal of Nutrition, 8(7), 1059-1061. http://dx.doi. org/10.3923/pjn.2009.1059.1061. 
Vetayasuporn, S., Chutichudet, P., \& Cho-Ruk, K. (2006). Bagasse as a possible substrate for Pleurotus oesterotus (Fr.) Kummen cultivation for the local mushroom farms in the Northeast of Thailand. Pakistan Journal of Biological Sciences, 9, 2512-2515. http://dx.doi.org/10.3923/ pjbs.2006.2512.2515.

Yang, G., Guo, F., \& Wan, Z. (2013). Yield and size of oyster mushroom grown on rice/wheat straw basal substrate supplemented with cotton seed hull. Saudi Journal of Biological Sciences, 20(4), 333-338. http:// dx.doi.org/10.1016/j.sjbs.2013.02.006. PMid:24235869.

Yang, X. M. (2000). Cultivation of Edible Mushroom (pp. 36). Beijing: China Agriculture Press.
Yildiz, S., Yildiz, U. C., Gezer, E. D., \& Temiz, A. (2002). Some lignocellulosic wastes used as raw material in cultivation of the Pleurotus ostreatus culture mushroom. Process Biochemistry, 38(3), 301-106. http://dx.doi.org/10.1016/S0032-9592(02)00040-7.

Zadrazil, F. (1980). Influence of ammonium nitrate and organic supplements on the yield of Pleurotus Sajor-Caju (Fries), Singer. European Journal of Applied Microbiology and Biotechnology, 9(1), 31-34. http://dx.doi.org/10.1007/BF00499999.

Zhang, R., Li, X., \& Fadel, J. (2002). Oyster mushroom cultivation with rice and wheat straw. Bioresource Technology, 82(3), 277-284. http://dx.doi.org/10.1016/S0960-8524(01)00188-2. PMid:11991077. 